\title{
Strategi Pemberdayaan Masyarakat Melalui Pengembangan Lebah Madu Kelompok Tani Tahura (KTT) (Studi Kasus di Desa Dilem Kecamatan Gondang Mojokerto)
}

\author{
Andika Adi Sanjaya Putra ${ }^{1}$, Darsono Wisadirana², Hilmy Mochtar ${ }^{3}$ \\ ${ }^{1}$ Graduate Program in Sociology Study of Poverty, University of Brawijaya, Indonesia \\ ${ }^{2}$ Faculty of Social and Political Science, University of Brawijaya, Indonesia \\ ${ }^{3}$ Faculty of Social and Political Science, University of Brawijaya, Indonesia
}

\begin{abstract}
Abstrak
Desa Dilem memiliki potensi ekonomi yang besar dari budidaya lebah madu. Berdasar data PPLS (Pendataan Program Perlindungan Sosial) pada tahun 2008 memiliki satu Kepala Keluarga (KK) miskin dan pada tahun 2011 meningkat menjadi 16 KK. Perlu dirumuskan strategi pemberdayaan masyarakat melalui pengembangan budidaya lebah madu dalam upaya penanggulangan kemiskinan pada Kelompok Tani Tahura (KTT) di Desa Dilem Kecamatan Gondang Kabupaten Mojokerto. Penelitian ini bersifat kualitatif deskriptif pendekatan studi kasus. Data penelitian diperoleh mengunakan adalah wawancara mendalam (indepth interview), observasi lapangan, dokumentasi dan Focus Group Discussion, kemudian dianalisis dengan teori pemberdayaan 5P edi Suharto, yaitu pemungkinan, penguatan, perlindungan, penyokongan dan pemeliharaan. Alternatif strategi yang dapat dirumuskan yaitu perlu adanya peran serta aktif dan kerjasama dalam berbagai bentuk antara berbagai pihak yang terkait antara lain Pemerintah Kabupaten Mojokerto, UPT Tahura R. Soerjo, Pemerintah Desa, Kelompok Tani Tahura (KTT) dan Petani Pembudidaya Lebah Madu.
\end{abstract}

Kata Kunci : Pemberdayaan Masyarakat, Kelompok Tani Tahura (KTT), Lebah Madu, pemberdayaan lebah madu.

\section{Abstract}

Dilem village has a great economic potential of beekeeping. Based on the data of PPLS (Data Collection Program of Social Protection) in 2008 has one families (KK) poor's and in 2011 increased to 16 families. It is necessary to formulate a strategy of community empowerment through the development of beekeeping to fight against poverty at Farmers Group Tahura (KTT) in the Dilem Village Gondang District of Mojokerto. This research used qualitative descriptive case study approach. The research data was obtained using in-depth interviews (depth interview), field observation, documentation and Focus Group Discussion, and then analyzed by the theory of empowerment 5P Edi Suharto, namely pemungkinan, penguatan, perlindungan, penyokongan and pemeliharaan (possibly, reinforcement, protection, smiles and sustainable). Alternative strategies can be formulated, namely the need for active participation and cooperation in various forms between the various parties involved, among others, Mojokerto regency government, UPT Tahura R. Soerjo, the Village Government, Farmers Group Tahura (KTT) and the Farmers cultivator of Bee Honey.

Keywords: Community Empowerment, Farmers Group Tahura (KTT), Bee Honey, poverty

\section{PENDAHULUAN}

Menurut data laporan Statistik tahun 2012 dari Direktorat Jendral Planologi Kementrian Kehutanan menyebutkan bahwa angka kerusakan hutan di Indonesia mencapai 450.637,1 Ha dan Jawa Timur menyumbang angka 1370,1 $\mathrm{Ha}$ [1]. Laju kerusakan hutan atau deforestasi yang terjadi sangatlah

Alamat Korespondensi Penulis: Andika Adi Sanjaya Putra, SE, MSi

Email : adisanjayaputra@gmail.com

Alamat : UPT. Peredaran Hasil Hutan, Jl. Karimata No. 20 Surabaya kode pos 60246 memprihatinkan mengingat luas hutan di Jawa Timur berdasarkan Keputusan Menteri Kehutanan RI Nomor: 395/Menhut-VII/2011 sebesar $1.363 .719,00$ atau $28 \%$ dari luas daratan [2]. Kenyataan ini termasuk golongan tidak ideal bagi kriteria hutan seperti yang diamanatkan oleh Undang Undang Nomor 41 Tahun 1999 yaitu luas kawasan hutan yang ideal adalah seluas $30 \%$ apabila dibandingkan dengan luas daratan [3].

Angka deforestasi ini relatif tinggi, jika dibiarkan cepat atau lambat hutan di Jawa Timur akan habis. Untuk menekannya, dibutuhkan langkah antisipatif dengan melibatkan masyarakat sekitar hutan, sebab mereka mempunyai keterkaitan yang erat secara 
ekonomi dan sosial dengan hutan. Kebijakan tersebut merupakan tindakan partisipatif yang didukung oleh Pemerintah dengan diterbitkannya Peraturan Menteri Kehutanan Nomor 39/Menhut-II/2013 tentang Pemberdayaan Masyarakat Setempat Melalui Kemitraan Kehutanan.

Berdasarkan hal tersebut, Dinas Kehutanan Provinsi Jawa Timur memberikan wewenang kepada UPT. Taman Hutan Raya (TAHURA) R. Soerjo agar bekerjasama dengan masyarakat sekitar hutan melalui berbagai macam program pemberdayaan. Salah satu programnya adalah pengembangan budidaya lebah madu. Program ini bertujuan agar terjadi simbiosis mutualisme antara masyarakat dengan lingkungan hutannya karena sumber makanan pokok terbesar dari lebah madu adalah nektar bunga yang berasal dari hutan, sehingga ketergantungan untuk ikut menjaga dan melestarikan hutan semakin besar.

Potensi pasar dari pengembangan lebah madu sangatlah besar, sebagaimana yang disampaikan Menteri Kehutanan Zulkifli Hazan dalam kunjungan kerja di Kabupaten Sumbawa hari minggu tanggal 11 Nopember 2012 bahwa kebutuhan madu nasional pertahunnya sekitar 50.000 ton pertahun, akan tetapi baru terpenuhi sekitar 12.000 ton pertahun [4]. Sedangkan kebutuhan madu di Provinsi Jawa timur menurut Dinas Perkebunan Provinsi Jawa Timur adalah sekitar 500 ton pertahun, baru bisa dipenuhi sekitar 300 ton pertahun [5].

Melihat potensi ekonomi yang besar dari budidaya lebah madu bagi peningkatan pendapatan masyarakat sekitar hutan di kawasan Tahura R. Soerjo, perlu sekali untuk dilaksanakan. Potensi ini berpeluang untuk menekan angka kemiskinan yang terjadi di kawasan sekitar Tahura R. Soerjo. Berdasar data PPLS (Pendataan Program Perlindungan Sosial) tahun 2008 dan 2011 dari Bappeda Provinsi Jawa Timur menyebutkan bahwa tingkat pertumbuhan penduduk miskin di Desa Dilem pada tahun 2008 adalah sebesar 1 (satu) Kepala Keluarga (KK) dan pada tahun 2011 meningkat menjadi 16 KK. Apabila di prosentase maka tingkat kenaikannya relative cukup tinggi yaitu sekitar $1500 \%$. Hal ini relative cukup tinggi dibandingkan dengan desadesa lainnya di Kecamatan Gondang Kabupaten Mojokerto yang berjumlah 18 desa.

Melihat potensi dan angka kemiskinan tersebut, dikembangkanlah penelitian dengan tujuan merumuskan strategi pemberdayaan masyarakat melalui pengembangan budidaya lebah madu dalam upaya penanggulangan kemiskinan pada Kelompok Tani Tahura (KTT) di Desa Dilem Kecamatan Gondang Kabupaten Mojokerto.

[6] menyatakan Pelaksanaan proses dan pencapaian tujuan pemberdayaan dicapai melalui penerapan pendekatan pemberdayaan yang dapat disingkat menjadi 5P, antara lain [6]:

1. Pemungkinan adalah menciptakan kondisi atau suasana yang memungkinkan potensi masyarakat berkembang secara optimal. Penciptaan kondisi yang memungkinkan masyarakat Desa Dilem untuk dapat berkembang lebih jauh dalam bidang ekonomi, adalah dengan menciptakan pemungkinan pemanfaatan potensi lokal yang ada di Desa Dilem.

2. Penguatan yaitu meningkatkan pengetahuan dan kemampuan masyarakat terutama berkaitan dengan potensi lokal sosial sehingga mampu untuk memecahkan masalah serta dapat berguna untuk memenuhi kebutuhan dasar hidupnya. Penguatan dapat berupa menjaga keberhasilan atau capaian hasil yang telah diperoleh, dalam proses pemberdayaan lebah madu di Desa Dilem. Salah satu yang dilakukan adalah, hasil panen budidaya lebah madu harus ditingkatkan kualitas dan kuantitasnya melalui penguatan yang dilakukan oleh berbagai pihak.

3. Perlindungan yaitu melindungi masyarakat terutama kelompok-kelompok lemah agar tidak tertindas oleh kelompok kuat. Perlindungan merupakan proses yang melindungi tahapan penguatan yang telah dicapai, dalam proses pemberdayaan lebah madu di Desa Dilem. Perlindungan ini menjaga agar tahapan penguatan yang telah dilakukan tidak mengalami kemunduran dan kegagalan.

4. Penyokongan yaitu memberikan bimbingan, penyuluhan dan dukungan agar masyarakat mampu mendapatkan akses informasi yang lebih sehingga mampu memanfaatkan peluang yang ada. Penyokongan dapat dilakukan melalui bimbingan dan penyuluhan kepada KTT (Kelompok Tani Tahura) Nambi Agung dan warga Desa Dilem agar mampu mengatasi kendala teknis yang terjadi dalam budidaya lebah madu.

5. Pemeliharaan yaitu situasi yang kondusif harus selalu terjaga dan terpelihara, hal ini bertujuan untuk menjaga keseimbangan peran kekuasaan antara berbagai 
kelompok dalam masyarakat. Pemeliharaan dalam budidaya lebah madu di Desa Dilem adalah proses menjaga secara sustainable atau berkelanjutan terhadap pencapaian hasil pemberdayaan selama ini.

Menurut [7] menyebutkan kemiskinan timbul karena ada sebagian daerah yang belum sepenuhnya tertangani, ada sebagian sektor yang harus menampung tenaga kerja berlebih dengan tingkat produktifitas yang rendah, dan ada pula sebagian masyarakat yang belum ikut serta dalam proses pembangunan sehingga belum dapat menikmati hasilnya secara memadai [7].

[7] menyebutkan yang menyebabkan perolehan pendapatan tidak seimbang, dan kemudian menimbulkan struktur masyarakat yang timpang. Kemiskinan yang disebabkan karena hasil pembangunan yang tidak seimbang ini juga dikenal dengan kemiskinan struktural.

Sedangkan kemiskinan kultural adalah kemiskinan yang muncul sebagai akibat adanya nilai-nilai atau kebudayaan yang dianut oleh orang-orang miskin, seperti malas, mudah menyerah pada nasib, kurang memiliki etos kerja dan sebagainya (Lewis, 1988) [8]

\section{METODE PENELITIAN}

Penelitian ini bersifat kualitatif dengan pendekatan deskriptif menggunakan metode studi kasus. Data penelitian kualitatif berupa data primer dan sekunder yang berupa kata-kata dan tindakan, selebihnya merupakan data tambahan seperti dokumen dan lain-lain [9]. Untuk memperoleh data tersebut metode pengumpulan data yang digunakan adalah wawancara mendalam (indepth interview), observasi lapangan, dokumentasi dan FGD (Focus Group Discussion). Data yang diperoleh kemudian dianalisis menggunakan pendekatan kualitatif diskriptif melalui berbagai tahapan yaitu pengumpulan data, kondensasi data, penyajian data, dan penarikan kesimpulan [10]. Selanjutnya dianalisa dengan teori pemberdayaan $5 \mathrm{P}$ edi Suharto, yaitu pemungkinan, penguatan, perlindungan, penyokongan dan pemeliharaan.

\section{Metode Pengumpulan Data}

Untuk memperoleh informasi dan data dalam penelitian ini, pertama kali yang dilakukan adalah menemukan informan kunci (key informan) yang mengetahui seluk beluk dan kondisi terkini dari lokasi penelitian terutama mengenai pemberdayaan masyarakat berbasis lebah madu di Desa Dilem. Teknik ini disebut purposive sampling. Informasi dan data awal yang diperoleh tersebut kemudian di konfirmasikan dengan informan lainnya yang ditemui pada lokasi penelitian sehingga keabsahan data dan informasinya dapat dipertanggung jawabkan kebenarannya.

Tabel I. Karakteristik Informan Berdasar Status

\begin{tabular}{|c|l|c|c|}
\hline No & \multicolumn{1}{|c|}{ Status } & Jumlah & Persentase \\
\hline 1 & Aparatur Desa & 2 & 18 \\
\hline 2 & Aparat TAHURA R. SOERJO & 3 & 27 \\
\hline 3 & Warga Desa Dilem & 5 & 46 \\
\hline 4 & Ketua KTT Nambi Agung & 1 & 9 \\
\hline \multicolumn{2}{|c|}{ Jumlah } & 11 & 100 \\
\hline
\end{tabular}

Sumber: Informasi dari informan dan dokumentasi

\section{HASIL DAN PEMBAHASAN}

KTT Nambi Agung berdiri sejak tahun 2011 dan beranggotakan seluruh masyarakat Desa, namun yang aktif didalam kepengurusannya berjumlah 25 orang. Pembentukan KTT ini pada awalnya untuk mengkoordinir warga desa didalam berbagai kegiatan yang berkaitan dengan pelestarian lingkungannya, seperti penghijauan, pembibitan dan berbagai program kemasyarakatan yang di lakukan oleh UPT Tahura R. Soerjo, namun akhirnya berkembang menjadi wadah bagi warga desa didalam mengembangkan potensi desanya yaitu budidaya lebah madu.

Berdasar hasil penelitian yang dilakukan, awal mula gagasan budidaya lebah madu bukan berasal dari Tahura R. Soerjo, melainkan dari warga masyarakat. Mereka ingin memanfaatkan potensi alam yang ada untuk memenuhi kebutuhan ekonominya. Gagasan ini kemudian ditindaklanjuti dengan pemberian bantuan stup atau rumah lebah madu disertai pelatihan teknis oleh Tahura R. Soerjo.

Dalam dokumentasi UPT. Tahura R. Soerjo menyebutkan bahwa program ini dilakukan secara bertahap di beberapa desa penyangga Tahura R. Soerjo. Pada tahun 2010 di Desa Gumeng mendapatkan bantuan sebanyak 25 stup, tahun 2011 Desa Dilem dan Begaganlimo mendapatkan bantuan sejumlah 50 stup. Jenis lebah yang di berikan sebagai bantuan adalah apis cerana (jenis lokal) dan apis melifera (jenis impor). Bantuan ini diberikan langsung kepada masing-masing kelompok tani yang ada di desadesa tersebut.

Sebelum diberikan bantuan stup oleh Tahura R. Soerjo, terlebih dahulu para anggota KTT dibekali dengan pengetahuan 
dan Pelatihan ketrampilan teknis budidaya lebah madu pada tanggal 24-25 Juli 2011 yang bertempat di Hotel Wisata Tidar Jl. Puncak Tidar No.1 Malang dan Peternakan "Rimba Raya" Jl. Dr. Wahidin 8 LawangMalang. Bantuan stup lebah madu diberikan pada bulan Nopember 2011 kepada KTT di wilayah Tahura R. Soerjo. Melalui musyawarah desa, KTT Nambi Agung di Desa Dilem memutuskan membagi secara merata ke seluruh warga Desa Dilem tanpa terkecuali baik anggota KTT atau bukan.

Pada saat panen awal, satu stup lebah madu menghasilkan keuntungan antara $\mathrm{Rp}$ 500.000 ,- sampai Rp 1.000.000,- . Para warga masyarakat yang merasakan manfaat ekonomis ini kemudian menambah stup madu yang mereka punyai dengan dana swadaya. Mereka berharap dengan memiliki stup madu yang semakin banyak maka hasil yang diperoleh juga ikut meningkat, apalagi dalam satu tahun dapat memanen sebanyak 4 kali.

Keberhasilan ini ternyata hanya dirasakan pada awal-awal pemberdayaan lebah madu. dari jumlah stup sebanyak 50 unit pada saat dilakukan monitoring berkurang menjadi 41 unit stup dalam kondisi baik, sedangkan yang 9 unit stup dalam kondisi kosong atau lebah tidak kembali lagi (minggat) dan diganti secara swadaya oleh masyarakat.

Penurunan hasil panen tersebut dipengaruhi oleh berbagai kendala yang terjadi. Kendala tersebut dibagi menjadi dua faktor yaitu faktor teknis dan non teknis. Salah satu faktor non teknis adalah kendala cuaca. Jika musim penghujan dengan intensitas curah hujan relatif tinggi, akan mengganggu produksi madu. Kendala cuaca sangat berpengaruh dalam keberhasilan budidaya lebah madu. Biasanya lebah akan keluar mencari makan pada pagi hari, tapi sewaktu siang hari kondisi cuaca berubah/hujan, menyebabkan lebah tidak bisa kembali ke sarangnya. Kurangnya minat generasi muda di Desa Dilem untuk menekuni budidaya lebah madu dan tidak dilibatkannya para wanita dalam proses pemberdayaan ini menjadi kendala bagi kelancaran proses pemberdayaan. Sistem penjualan yang dilakukan tanpa koordinasi serta masih menggunakan cara-cara konvensional sangat rentan akan persaingan harga yang tidak terkontrol. Belum adanya labeling terhadap produk madu dari Desa Dilem akan mengurangi daya saing dengan produk madu dari daerah lainnya.
Salah satu kendala teknis yang terjadi adalah tidak adanya alat pemisah madu. Alat ini sangat penting dalam memisahkan madu dari stup tanpa merusaknya. Dengan tidak dirusaknya stup (diperas) maka lebah dapat menggunakan sarangnya tanpa harus membuatnya kembali. Sehingga masa panen dapat lebih cepat. Sebagai perbandingan, jika pengelolaan secara tradisional hanya mampu memanen madu 4-5 kali pertahun, sedangkan jika menggunakan alat tersebut panen bisa dilakukan setiap 1-2 bulan sekali, karena lebah madu tidak usah membuat sarangnya lagi. Hama menjadi kendala teknis yang bisa mempengaruhi penurunan hasil panen karena beberapa binatang seperti semut dan cicak serta binatang pemakan lebah sangat mengganggu eksistensi lebah. Keracunan pestisida juga memberikan dampak yang relatif berpengaruh dari kegagalan panen lebah madu, sebab banyak lebah madu yang mati saat mencari makan sehingga stup lebah madu menjadi kosong. Kendala teknis yang tidak kalah penting adalah tidak adanya pendampingan yang berkelanjutan dari Tahura R. Soerjo. Proses pendampingan ini sangat penting untuk memantau perkembangan dan memantau kendala dalam budidaya lebah madu agar dicarikan solusi dengan segera mungkin.

Salah satu kelebihan dari budidaya lebah madu di Desa Dilem adalah mereka tidak mengalami kesulitan dalam pemasaran produknya karena sudah mempunyai langganan tetap. Sebagai info harga dari tiap botol lebah madu ukuran $600 \mathrm{ml}$ adalah 150.000,-. Harga ini dibentuk berdasarkan kesepakatan anggota KTT Nambi Agung dan juga para warga.

Berdasarkan hasil informasi diatas secara ekonomis dapat diperhitungkan kontribusi hasil budidaya lebah madu pada KTT (Kelompok Tani Tahura) didesa ini sebagai berikut :

Tabel 2. Analisa Ekonomi budidaya lebah madu pada KTT di Desa Dilem

\begin{tabular}{|c|l|l|}
\hline 1. & Pendapatan Perstup (rata-rata) & Rp. 750.000,- \\
\hline 2. & Pendapatan total (50 stup) & Rp. 37.500.000,- \\
\hline 3. & $\begin{array}{l}\text { Pendapatan rata-rata anggota } \\
\text { perpanen (25 orang) }\end{array}$ & Rp. 1.500.000,- \\
\hline 4. & $\begin{array}{l}\text { Pendapatan rata-rata anggota } \\
\text { pertahun (4 kali panen) }\end{array}$ & Rp. 6.000.000,- \\
\hline 5. & $\begin{array}{l}\text { Pendapatan rata-rata anggota } \\
\text { perbulan }\end{array}$ & Rp. 500.000,- \\
\hline
\end{tabular}

Sumber : Data Primer dan Sekunder diolah 
Namun produksi madu dari waktu ke waktu mengalami penurunan yang signifikan, seperti tampak pada tabel berikut ini:

Tabel 3. Data Hasil Panen Lebah Madu Di Desa Dilem

\begin{tabular}{|c|c|c|}
\hline No & Tahun & Jumlah dalam Botol \\
\hline 1 & 2011 & 150 \\
\hline 2 & 2012 & 75 \\
\hline 3 & 2013 & 40 \\
\hline
\end{tabular}

Ket: 1 botol $=600 \mathrm{ml}$

Sumber: Data Primer diolah

Data hasil panen diatas tampak terjadi penurunan yang cukup signifikan. Penurunan jumlah madu tersebut disebabkan semakin berkurangnya ketersediaan pakan lebah madu karena kebakaran hutan yang terjadi hampir setiap tahun di Kawasan Tahura R. Soerjo. Hal tersebut berdampak terhadap pendapatan anggota Kelompok Tani Nambi Agung yang berjumlah 25 orang pertahunnya. Apabila dibagi dalam pendapatan perorang perbulan dapat dilihat pada grafik 5.3 di bawah ini.

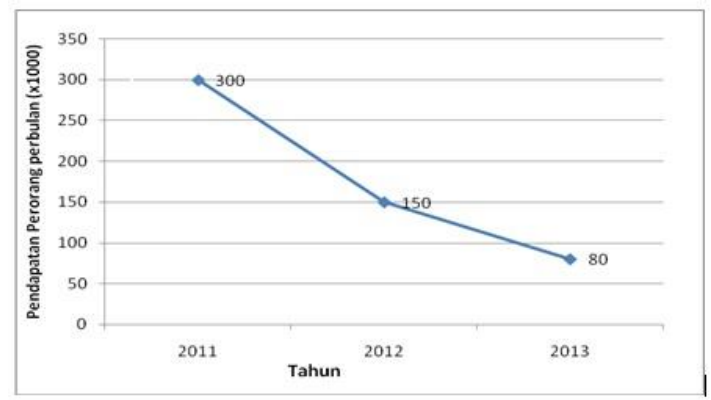

Gambar 1. Grafik perkembangan pendapatan anggota kelompok tani tahura perorang perbulan (x1000) dari tahun 2011 hingga 2013.

Berbagai upaya telah dilakukan Tahura R. Soerjo untuk mencegah dan mengurangi kerusakan akibat kebakaran hutan. Penyuluhan kepada masyarakat selalu di lakukan secara formal maupun non formal. Namun hasilnya belum seperti yang diharapkan. Masih perlu adanya kerjasama yang baik dengan instansi lainnya diluar Tahura R. Soerjo.

\section{ANALISA PEMBERDAYAAN (5P)}

\section{Pemungkinan}

Pola yang terjadi tersebut dapat digambarkan seperti pada gambar 5.4 dibawah ini. Pada dasarnya di Desa Dilem rata-rata penduduknya tidak memiliki lahan pertanian, sehingga mereka hanya menjadi buruh tani di desa lain. Namun demikian, desa ini terletak ditepi hutan konservasi Tahura R. Soerjo, yang mempunyai potensi untuk budidaya lebah madu. Sebelumnya masyarakat tidak mengetahui potensi tersebut, tetapi pihak Tahura yang mengetahuinya dan berusaha membantu masyarakat dengan memanfaatkan potensi hutan untuk budiaya lebah madu. Tahura R. Soerjo memberikan bantuan berupa stup madu, bibit dan pelatihan budidaya kepada anggota KTT (Kelompok Tani Tahura) Nambi Agung.

Hasil pemanfaatan budidaya lebah madu saat ini sudah dilakukan beberapa kali panen semenjak diberikannya bantuan oleh Tahura, namun dari catatan KTT Nambi Agung untuk 3 tahun terakhir, hasilnya cenderung terjadi penurunan yang cukup signifikan. Berdasarkan analisa secara ekonomi pada sub bab implementasi dijelaskan, bahwa pada awal masa budidaya rata-rata peternak lebah madu dapat memperoleh penghasilan kotor perbulan lima ratus ribu rupiah. Secara ekonomi nominal sebesar itu tidaklah mencukupi guna memenuhi kebutuhan anggota keluarga jika budidaya ini dimanfaatkan sebagai mata pencarian utama, karena hanya bisa dikatakan sebatas membantu menambah penghasilan keluarga.

Dampaknya secara sosial dapat dirasakan hampir semua anggota KTT (Kelompok Tani Tahura) Nambi Agung, dimana dengan adanya kegiatan budidaya ini mereka merasakan beban hidupnya relatif lebih ringan. Kegiatan proses pemberdayaan ini juga memberikan dampak berupa peningkatan ikatan emosional antar anggota dan masyarakat, dan tumbuhnya komunikasi yang lebih baik diantara mereka, sehingga mereka dapat saling membagi beban hidup yang dialami.

Saat ini kondisi hutan konservasi Tahura R. Soerjo sudah semakin menurun, dikarenakan sering terjadi pembakaran hutan oleh oknum yang tidak bertanggung jawab. Sebagai akibatnya menyebabkan terjadinya penurunan ketersediaan pakan untuk lebah yang dibudidayakan oleh masyarakat anggota kelompok KTT Nambi Agung. Inilah yang memicu penurunan kuantitas produksi madu dan penurunan pendapatan petani yang bersangkutan, yang pada akhirnya akan mempengaruhi kondisi sosial ekonomi masyarakat anggota KTT (Kelompok Tani Tahura) di Desa Dilem. Pola yang terjadi tersebut dapat digambarkan seperti pada Gambar 5.4 dibawah ini. 


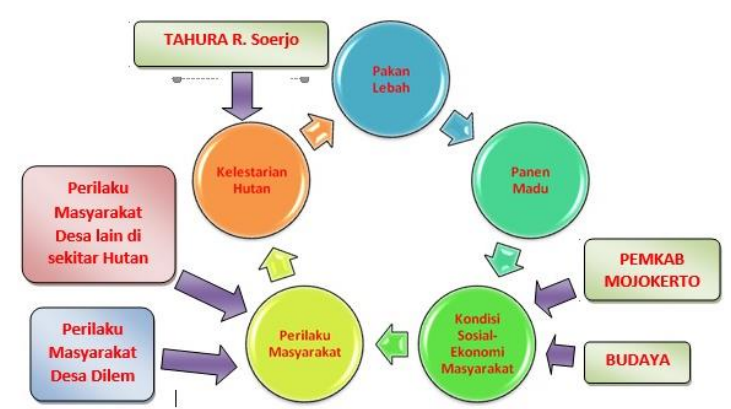

Gambar 5.4. Pola Pemungkinan dalam budidaya LebahMadu di Desa Dilem

Untuk dapat merubah pola perilaku masyarakat desa lain di sekitar hutan Konservasi Tahura, pihak Tahura harus memikirkan pula bagaimana cara merubah pola perilaku mereka terhadap hutan. Tahura R. Soerjo dapat mengembangkan usaha pemberdayaan seperti yang dilakukannya di Desa Dilem, namun tetap berdasarkan potensi yang dimiliki desa-desa tersebut.

\section{Penguatan}

Tahura R. Soerjo merupakan satu-satunya lembaga yang saat ini telah mengucurkan bantuan sarana dan prasarana, serta pelatihan untuk peningkatan kapasitas dalam budidaya lebah madu kepada masyarakat anggota kelompok tani di Desa Dilem. Setelah bantuan stup madu diberikan pada bulan Nopember 2011, Ketua KTT melalui musyawarah desa memutuskan untuk membagi secara merata ke seluruh warga Desa Dilem tanpa terkecuali, baik anggota KTT atau bukan. Bantuan dari Tahura mampu meningkatkan kemampuan untuk memenuhi kebutuhan dasar hidup masyarakat miskin, meskipun baru sekedar sebagai tambahan pendapatan, itupun dari waktu ke waktu nominalnya cenderung menurun.

Sebelum bantuan diberikan ke masyarakat, Tahura mempersiapkan dan membekali peserta program pemberdayaan ini dengan memberikan pengetahuan dan ketrampilan seputar teknis budidaya lebah madu melalui suatu pelatihan. Pelatihan ketrampilan teknis budidaya lebah madu dilaksanakan tanggal 24-25 Juli 2011, bertempat di Hotel Wisata Tidar Jl. Puncak Tidar No.1 Malang (Pembukaan dan Pengarahan) dan Peternakan "Rimba Raya" Jl. Dr. Wahidin 8 Lawang-Malang (Praktik Pelatihan).

$$
\text { Selanjutnya dalam program }
$$

pemberdayaan ini, Tahura melakukan monitoring dan evaluasi (monev) secara kontinyu dan berkala. Namun sayangnya, aktifitas monev tersebut hanya sekedar kegiatan rutinitas tanpa ada tindak lanjut dari hasilnya. Seperti yang telah terjadi saat ini di Desa Dilem, dimana terus terjadi penurunan produksi madu. Salah satu penyebabnya adalah kelangkaan pakan lebah madu dikarenakan adanya hutan akibat pembakaran lahan hutan oleh oknum yang tidak bertanggung jawab.

Dari permasalahan tersebut, Tahura $R$. Soerjo sebagai pihak pengelola kawasan konservasi sudah berusaha melakukan kegiatan preventif dan persuasif dengan memberikan penyuluhan kepada masyarakat. Kegiatan tersebut untuk memberikan edukasi tentang betapa pentingnya menjaga kawasan hutan di lingkungan mereka. Penyuluhan tersebut tidak bisa dibatasi oleh waktu, karena pemahaman dari setiap individu di desa-desa kawasan Tahura R. Soerjo sangatlah beragam dan harus dilaksanakan setiap waktu.

Menurunnya jumlah pakan lebah madu merupakan efek dari kerusakan hutan yang terjadi. Solusi alternatif yang bisa dilakukan oleh Tahura adalah dengan mengarahkan dan melatih warga masyarakat di Desa Dilem untuk menanam jenis-jenis tanaman yang menjadi pakan lebah. Budidaya tanaman ini dapat dijadikan sebagai alternatif lain pemenuhan pakan lebah madu, dan tidak hanya menggantungkan diri hutan. Untuk kegiatan budidaya tanaman in,i dapat memanfaatkan tenaga SDM ( Sumber Daya Manusia) wanita di desa ini, yang selama ini peranannya kurang dalam proses pemberdayaan ini. Di desa Dilem tercatat dari 77 Kepala Keluarga terdapat 137 orang laki-laki dan 119 orang perempuan (termasuk anak-anak) dari jumlah penduduk total 256 orang (BPS 2013), sehingga jumlah SDM Perempuan ini sangat berpotensi untuk mendukung program pemberdayaan berbasis budidaya lebah madu yang saat ini telah dikelola oleh para pria.

Pemberdayaan perempuan ini berpotensi untuk dikembangkan seperti pada hasil penelitian Evy Maharani, Susy Edwina Dan I'eni Kusumawaty (2008: 30-36) di Desa Jayapura, Kecamatan Bunga Raya Kabupaten Siak, dimana peran kaum ibu dalam membantu ekonomi keluarga semakin penting dalam kondisi krisis ekonomi, salah satunya melalui usaha budidaya tanaman hias. Berdasarkan hasil analisis pada penelitian ini dapat disimpulkan bahwa: 1) Provinsi Riau memiliki potensi besar dalam pengembangan tanaman hias dataran rendah, yang didukung oleh iklim dan letaknya yang strategis, 2) Usaha budidaya tanaman hias sangat sesuai sebagai alternatif pemberdayaan masyarakat termasuk ibu rumah tangga, karena 
dapat dilakukan di pekarangan tanpa meninggalkan peran penting sebagai ibu dan pendidik generasi penerus.

Dari data BPS Kecamatan Gondang 2013 tampak Desa Dilem tidak memiliki lahan pertanian yang berupa sawah. Di desa yang memiliki luas wilayah 0,95 km2 ini, hanya ada lahan kering seluas $6.412 \mathrm{~m} 2$ dan pekarangan rumah. Bila kita mengacu pada hasil penelitian [11] di Desa Lampeapi Provinsi Sulawesi Selatan, dimana penduduknya memanfaatkan pekarangan rumahnya untuk memenuhi kebutuhan pangan keluarganya dengan menanam berbagai jenis tanaman yang sesuai. Dari sini kita dapat mengadaptasi hasil penelitian tersebut dan menyesuaikan dengan kebutuhan yang dihadapi warga Desa Dilem.

Jenis tanaman yang dikembangkan disini berbeda jenisnya yaitu tanaman penunjang kebutuhan pangan lebah madu. Pemilihan jenis tanamannya dapat dilakukan berdasarkan hasil penelitian Sulistiorini (2006) dari Institut Pertanian Bogor yang berjudul "Inventarisasi Tanaman Pakan Lebah Apis Cerana Ferb Di Perkebunan Teh Gunung Mas Bogor dimana diketahui ada 57 jenis tanaman yang berperan sebagai tanaman sumber pakan lebah madu.

Berdasarkan dari penelitian yang dilakukan Mulyati Rahayu dan Sulistiorini maka masyarakat dan anggota kelompok tani di sini seharusnya juga perlu mendapatkan pelatihan untuk pemilihan, penanaman dan pembudidayaan tanaman sumber pakan lebah madu, khususnya untuk para wanitanya. Pelatihan dapat diberikan oleh pihak Tahura R. Soerjo sebagai penguatan program yang telah dilaksanakan sebelumnya, ataupun juga oleh Pemerintah Kabupaten Mojokerto dalam rangka pelaksanaan salah satu strategi RPJMD pada kluster 12(e) yaitu "Memperluas basis kesempatan berusaha serta menumbuhkan wirausaha baru berkeunggulan termasuk mendorong peningkatan ekspor".

Jika program budidaya tanaman sumber pakan lebah madu dikembangkan di Desa Dilem, maka akan berpotensi mendatangkan pendapatan tambahan lain dari penjualan tanaman yang di budidayakan jika sudah berlebihan stoknya. Jenis tanaman sumber pakan lebah sangatlah beragam, diantaranya jenis tanaman bunga, tanaman berbuah dan lain-lain.

Selanjutnya untuk lebih bersinerginya antara program-program pemberdayaan yang dilaksanakan Tahura sebagai salah UPT di Dinas Kehutanan Provinsi Jawa Timur dengan
Pemerintah Kabupaten Mojokerto selaku pemilik wilayah, perlu adanya komunikasi, koordinasi dan integrasi antara kedua lembaga tersebut, sehingga dapat saling melengkapi dan tidak tumpang tindih.

Pola Penguatan dalam budidaya Lebah Madu di Desa Dilem tampak pada gambar 5.5. dibawah ini.

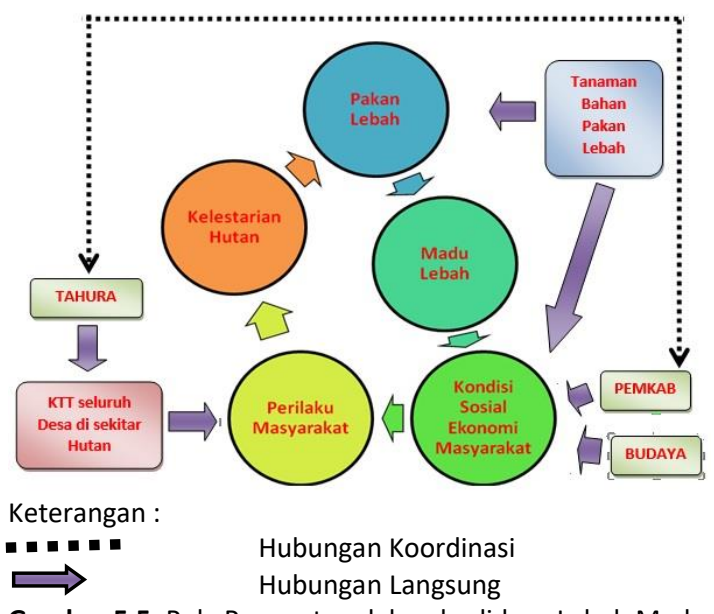

Gambar 5.5. Pola Penguatan dalam budidaya Lebah Madu di Desa Dilem

\section{Perlindungan}

Biasanya masyarakat dan anggota kelompok tani di sini mencari informasi jika menemui kendala dalam usahanya, dengan berkonsultasi langsung kepada anggota kelompok lain yang lebih berpengalaman dalam usaha budidaya lebahnya. Untuk saat ini, cara tersebut dirasa cukup membantu dalam memecahkan permasalahan yang dihadapi. Jika kita lihat lagi tren perkembangan usaha budidaya lebah di Desa Dilem saat ini cenderung terjadi penurunan, hal tersebut mengindikasikan bahwa sebenarnya cara ini relatif kurang efektif, namun mereka tidak punya pilihan lain.

Lokasi desa yang relatif terpencil dan jauh dari pusat kecamatan $(8,3 \mathrm{~km})$, menyebabkan fasilitas komunikasi dan infrastruktur IT (Informasi dan Teknologi) kurang dapat menjangkaunya. Ditambah lagi dengan ketiadaan fasilitas penunjang dan keterbatasan kemampuan masyarakat dan anggota kelompok tani dalam menggunakan IT, sehingga perlu juga bantuan dalam bentuk peralatan IT untuk masyarakat, agar dapat mengakses informasi yang mereka butuhkan di internet.

Generasi muda di desa yang tidak tertarik dengan budidaya lebah madu seperti orang tuanya, menyebabkan pemberdayaan ini kurang berjalan dengan baik, karena kurangnya sumbangsih pikiran dan inovasi pemuda- 
pemudinya. Mereka lebih suka bekerja di sektor lain di luar desa, yang menurut mereka lebih menjanjikan dalam memperoleh penghasilan untuk mencukupi kebutuhan hidupnya, sehingga praktis tidak ada dukungan IT dan tidak ada penerus usaha ini kedepannya. Berkaitan dengan hal tersebut, desa ini membutuhkan pelatihan kewirausahaan bagi generasi mudanya untuk menumbuh kembangkan jiwa dan semangat wirausaha, supaya menggapai kemandirian berbasis potensi lokal daerah. Pelatihan kewirausahaan ini memerlukan adanya peran serta pihak lain, khususnya peran Pemerintah Kabupaten Mojokerto.

Selain kegiatan pelatihan, Pemerintah Kabupaten melalui Dinas Pertanian perlu untuk merevitalisasi web yang dimilikinya (http://pertanian.mojokertokab.go.id/), sebagai media konsultasi dan informasi bagi semua petani di wilayahnya. Revitalisasi web ini bisa dilakukan dengan cara menyiapkan buku-buku elektronik terkait panduan teknis di bidang pertanian dan peternakan, sehingga masyarakat dapat langsung belajar dan berkonsultasi di web tersebut, yang relatif lebih efisien dan lebih efektif.

Di Desa Dilem fasilitas umum seperti perpustakaan bagi warga desa sangatlah minim. Kurangnya fasilitas tersebut sangat berpengaruh terhadap pengembangan pengetahuan masyarakat desa, mengakibatkan sulitnya warga desa mencari informasi, terkait usaha budidaya lebah madu yang mereka kembangkan. Namun demikian, apabila mereka harus mencari informasi di kota yang jaraknya cukup jauh, kendala yang mereka hadapi adalah keterbatasan biaya, baik untuk biaya transportasi maupun biaya untuk membeli buku. Pendirian taman baca ataupun perpustakaan umum di Desa Dilem akan memberikan kemudahan warga dalam menambah pengetahuan yang mereka butuhkan. Pengetahuan tersebut sangat berguna bagi pengembangan potensi lokal desa seperti pertanian, perkebunan, peternakan dan yang lainnya. Untuk menjawab kebutuhan tersebut, perlu adanya bantuan dari instansi terkait, terutama Pemerintah Kabupaten Mojokerto untuk mensuport masyarakat di desa ini dengan buku-buku yang mereka butuhkan.

\section{Penyokongan}

Dalam kondisi yang ideal, pemberian bimbingan teknis (Bimtek) dalam bentuk pelatihan sangatlah berguna bagi kelangsungan program pemberdayaan ini. Bimbingan merupakan satu paket untuk mengetahui seberapa jauh perkembangan dari kegiatan yang telah dilaksanakan, sehingga proses pembinaan tetap berjalan. Sayangnya, kegiatan ini hanya dilakukan sekali saja selama proses pemberdayaan pengembangan lebah madu digulirkan. Bimbingan ini merupakan faktor yang sangat penting untuk menjamin keberlanjutan kegiatan pemberdayaan ini (sustainability), sedangkan bimbingan dari pihak lain terkait cara memperoleh informasi budidaya lebah madu juga belum pernah ada.

Pemerintah Kabupaten Mojokerto seharusnya dapat melakukannya melalui Dinas Pertanian Kabupaten, namun karena data BPS menunjukkan bahwa di Desa Dilem tidak terdapat lahan pertanian produktif yang signifikan (sawah dan ladang), maka bimbingan itu tidak dilakukan. Ketiadaan bantuan dari Pemerintah Kabupaten Mojokerto terkait permasalahan pemberdayaan ini bisa juga terjadi karena ketidaktahuan mereka. Kurangnya komunikasi lintas sektoral menjadi salah satu alasannya, ditambah lagi kurangnya peran serta aparatur Pemerintahan Desa (Pemdes) dalam mendata serta melaporkan kegiatan pemberdayaan ini ke Instansi terkait di Kabupaten Mojokerto. Apabila data perkembangan budidaya lebah madu ini dimasukkan kedalam data base kegiatan ekonomi desa ditingkat kecamatan, maka dapat terinput ke data kegiatan pertanian di tingkat Kabupaten. Sehingga Pemerintah Kabupaten Mojokerto dapat ikut memantau perkembangan yang terjadi di wilayahnya.

\section{Pemeliharaan}

Seperti halnya kehidupan masyarakat desa di pulau Jawa pada umumnya, masyarakat Desa Dilem masih bersifat tradisional didalam menjalani kehidupan sosialnya. Keadaan ini biasanya terdapat pada masyarakat agraris yang hidup dari sektor pertanian. Salah satu ciri dari masyarakat tradisional adalah rasa hormat terhadap anggota masyarakat yang dituakan atau menjadi panutan warga, karena kedudukannya dalam organisasi di desa tersebut seperti Kepala Dusun, Ketua RT/RW dan juga Ketua Kelompok Tani. Dengan kata lain, budaya paternalistik masih sangat terasa tanpa mengurangi peran serta dari setiap warga desa.

Sikap anggota masyarakat yang dituakan atau menjadi panutan warga, terhadap masyarakat dan anggota kelompok tani di sini relatif baik. Didalam memutuskan suatu permasalahan dilakukan dengan musyawarah untuk mufakat, sehingga banyak kegiatan gotong 
royong dalam membangun fasilitas umum dan pembangunan jalan di seputar desa, dikerjakan secara swadaya oleh masyarakat berdasarkan hasil keputusan musyawarah. Bahkan, apabila ada rumah salah satu warga yang kondisinya tidak layak huni, masyarakat secara sukarela melakukan kegiatan bedah rumah secara bersama-sama. Bukan sampai disitu saja, apabila ada warga desa yang sakit parah, masyarakat secara sukarela mengumpulkan dana swadaya untuk berobat.

Pengaruh para pemuka masyarakat dalam membina dan mengarahkan tentang tradisi kemasyarakatan di Desa Dilem sangatlah positif. Peran serta mereka dan pengaruhnya sangat terasa sekali dalam menjaga stabilitas dan arah kehidupan sosialnya, sehingga dampak keberadaan anggota masyarakat yang dituakan atau menjadi panutan tersebut terhadap masyarakat dan anggota kelompok tani di sini sangatlah baik dan mempedulikan mereka.

\section{KESIMPULAN}

Berdasarkan hasil analisa pemberdayaan $5 p$ dari Edi suharto, kita dapat menentukan alternatif strategi yang tepat untuk meningkatkan optimalisasi pemberdayaan pada Kelompok Tani Tahura berbasis budidaya lebah madu di desa Dilem memerlukan peranan beberapa pihak untuk melakukan pekerjaan sesuai kapasitasnya, antara lain :

1. Pemerintah Kabupaten Mojokerto

- Memberikan Penguatan Modal atau memfasilitasi untuk mendapatkan pinjaman permodalan tanpa agunan, baik melalui bank maupun fasilitas kredit mikro lain .

- Memperbaiki Jalan akses ke desa

- Bantuan dalam bentuk peralatan IT untuk masyarakat agar dapat mengakses informasi yang mereka butuhkan di internet.

- Pelatihan kewirausahaan bagi generasi mudanya untuk menumbuh kembangkan jiwa dan semangat wirausaha berbasis potensi lokal daerah

- Dinas Pertanian perlu untuk merevitalisasi web yang dimilikinya (http://pertanian.mojokertokab.go.id/) sebagai media konsultasi dan informasi bagi semua petani di wilayahnya,

2. UPT Tahura R. Soerjo
- Memberlakukan program yang sama (budidaya lebah madu) di desa lain di sekitar hutan Tahura.

- Pendampingan kegiatan oleh Tahura atau instansi terkait

- Komunikasi, koordinasi dan integrasi antara Tahura dengan Pemerintah Kabupaten

- Menggunakan Teknologi Tepat Guna (TTG) berupa peralatan pemisah madu

3. Pemerintah Desa

Menginput ke data kegiatan budidaya lebah madu di desanya ke tingkat Kabupaten melalui BPS Kecamatan Gondang

4. Kelompok Tani Tahura (KTT)

Penyuluhan oleh pengurus KTT maupun ceramah-ceramah oleh tokoh masyarakat dan pemuka agama untuk meningkatkan motivasi masyarakat

5. Petani Pembudidaya Lebah Madu

Meningkatkan peranan wanita dengan menanam Tanaman bahan pakan lebah madu di pekarangan rumahnya untuk mendukung budidaya lebah madu.

\section{SARAN}

Berdasarkan kesimpulan diatas maka ada beberapa hal yang perlu dilakukan pembenahan sehingga tujuan pemberdayaan ini dapat tercapai secara optimal, antara lain :

1. Pemerintah Kabupaten Mojokerto perlu mendukung program perberdayaan dengan melakukan penguatan terhadap kegiatan yang sudah berjalan dan memperbaiki infrastruktur desa.

2. Dinas Pertanian Kabupaten Mojokerto perlu merevitalisasai web yang dimilikinya sebagai media informasi dan konsultasi bagi petani di wilayahnya.

3. UPT Tahura R. Soerjo perlu melakukan pendampingan kepada anggota KTT (Kelompok Tani Tahura) Nambi Agung

4. KTT (Kelompok Tani Tahura) Nambi Agung dan petani perlu membudidayakan tanaman bahan pakan lebah madu.

\section{UCAPAN TERIMA KASIH}

Terima kasih kami ucapkan kepada

Dr.H.Soekarwo,SH, M.Hum selaku Gubernur Jawa Timur, Dekan Fakultas IImu Sosial dan Ilmu Politik Universitas Brawijaya Prof.Dr.Ir.Darsono Wisadirana M.S, yang juga selaku Pembimbing Utama, M.S kemudian kepada Ketua Program Magister IImu Sosial dan IImu Politik 
Prof.Dr.Ir.Sanggar Kanto, M.Si, dan Dr. Drs. Hilmy Mochtar, MS selaku pembimbing kedua.

\section{DAFTAR PUSTAKA}

[1]. Kemenhut. 2013. Statistik Kawasan Kehutanan 2012. Dirjen Planologi Kehutanan Kemenhut Jakarta.

[2].http://dishut.jatimprov.go.id/berita2.php?id=53 diunduh pada tanggal 13-04-2015 pukul 10.00 wib.

[3]. Kemenhut. Undang-Undang Nomor 41 Tahun 1999 Tentang Kehutanan.

[4].http://www.dephut.go.id/INFORMASI/HUMA S/LEBAH.htm diunduh pada tanggal 18-032015 pukul 21.00 wib.

[5].http://www.disbun.jatimprov.go.id/berita.ph p?id=67 diunduh pada 19-9-2014 pada pukul 16.45 wib

[6]. Suharto, Edi. 2010. Membangun Masyarakat Memberdayakan Rakyat Kajian Strategis Pembangunan Kesejahteraan Sosial dan Pekerjaan Sosial, Bandung.

[7].Sumodiningrat,Gunawan.1999.Pemberdayaan Masyarakat dan Jaring Pengaman Sosial. Gramedia Pustaka Utama. Jakarta

[8]. Lewis, Oscar. 1988. Kisah 5 Keluarga (Telaah kasus Orang Meksiko Dalam Kebudayaan Kemiskinan), Yayasan Obor Indonesia, Jakarta.

[9]. Moleong, Lexy.J, 2012. Metodologi Penelitian Kualitatif, Edisi Revisi, P.T. Remaja Rosdakarya, Bandung.

[10]. Miles, Matthew B dan Huberman, A.Michael. 1992. Analisa Data Kualitatif. UI Press. Jakarta ,2014.Qualitative Data Analysis, United State of America. Arizona State University

[11]. Mulyati Rahayu, 2005, Keanekaragaman Tanaman Pekarangan Dan Pemanfaatannya Di Desa Lampeapi, Pulau Wawoni - Sulawesi Tenggara, Jurnal Teknologi Lingkungan, Bppt, Vol 6, No 2 (2005) > Rahayu, diunduh dari http://digilib.bppt.go.id/ejurnal/index.php/JT L/article/view/425 pada 16-02-2015 jam 02.45 WIB

[12]. Maharani, Evy, Susy Edwina Dan I'eni Kusumawaty, 2008, Peluang Usaha Budidaya Tanaman Hias Dalam Rangka Pemberdayaan Ibu Rumah Tangga, Diunduh Dari Https://Repository.Unri.Ac.Id/Handle/123456 789/5674 pada 16-02-2015 jam 02.55 WIB 